\title{
Empirical Study of Farmers' Income Increase Brought by the Development of Tourism Industry in the Ethnic Minority Area in the South Xinjiang--Using Bazhou and Jing County as Examples
}

\author{
Huang Dengbin, Yu Xiaoling \\ College of Economic and Management, Tarim University, Alar, Xinjiang, 843300
}

Keywords: rural tourism; farmers' income increase; employment; empirical analysis; ethnic minorities in south Xinjiang

\begin{abstract}
The tourism industry has a significant impetus to the development of the national economy. The development of tourism in ethnic areas has unique advantages and great achievements. Bazhou and Jing County have promoted the economic growth through the development of tourism, and promoted the farmers' income increase. The results show that the tourism industry has an indirect effect on the promotion of farmers' income by using the total income of tourism and the per capita net income of farmers in Bazhou and Jing County in 2002 and 2014. To promote the new rural construction in Xinjiang ethnic minority areas and the integration of urban and rural development has important practical significance.
\end{abstract}

\section{Introduction}

With the rapid development of the economy and the improvement of people's living standards, people who have solved the material life have a stronger desire for the different cultural lives; tourism consumption is increased significantly. The cultural and tourism resources of the ethnic areas are abundant, with huge development potential. To promote economic growth and improve the income increase of farmers is an important way to promote the economic, social and cultural development of ethnic areas. Through the development of special tourism, Bazhou and Jing County have become the the provincial-level famous tourism culture cities of economic development, cultural prosperity, national unity, people harmony that enjoy reputation at both home and abroad. The proportion of the total tourism revenue in the GDP of Bazhou and Jing County is growing. Although the special tourism industry in Bazhou and Jing County have yielded abundant fruits, yet the tourism economy has not well benefited the farmers in the most need of changing the economic conditions. In 2014, the per capita net income of farmers in Bazhou and Jing County was 12570 yuan.In the rapid development, can the tourism industry becomes the engine that promotes the development ofBazhou and Jing County and an important tool to increase per capita net income, which is worthy of serious research. With the tourism industry being promoted in the world, many domestic and foreign experts and scholars have been committed to the research of tourism economy in this area.

The existing literature at home and abroad has made a lot of research on the impact of the tourism industry on economic growth, job hunting,the social structure. Combining John M. Keynes' theory of multiplier, some scholars have analyzed the multiplier effect of tourism. In the 1970s, B. Archer and R. Vaughan verified the multiplier effect of the tourism industry on the economy through field trips, and studied the local employment situation in combination with the tourism multiplier effect. Zhou et al used the CUE general equilibrium model and input-output to analyze the economic effects of the tourism industry in Hawaii in response to Copeland Adams and Pamener's"structural effects of tourism expansion". Retitling Douglas and C. Horvath Ender used the "input-output analysis" approach to measure the contribution value of the tourists' consumption in the entire regional economy. E-dith Saivas and Michael Riley pointed out that in the process of 
socio-economic transformation, the disadvantaged groups in the job market will turn to the tourism industry; the "tourism satellite" developed by the World Tourism Organization Accountis currently an important tool for studying the regional economic impact of tourism, which has been widely usedin developed countries and developing countries in Europe and America. Domestic scholars' researches on the tourism economy is mainly interpretation and publicityof the tourism industry's status, role and nature in the national economy, as well as the comparison of the domestic and international tourism development so as to propose suggestionsfor the development of the tourism industry. According to the characteristics of the tourism industry and the poverty connotation, Wei Xiao'an analyzes the important role of the tourism industry in improving the level of poverty alleviation and development, and indicates to improve the development of the tourism industry to alleviate poverty from "highlighting three advantages, making clear three weaknesses, dealing with three relations, strengthening three constructions". Run Min, through detailed data, demonstrates the necessary connections between the industrialization of the tourism industry and the development level of the national economy; only after the industrialization can the tourism industry enter the industrialization stage. Jiang Guiyan and Li Shengmei conduct the empiral researches of the relations between tourism industry and the economic development in Qinghai Province. The results show that tourism industry and the national economy in Qinghai Province have the positive interaction; co-tourism and special tourism are the best choices for he sustainable development of its tourism. Wang Yonggang uses the nonparametric Malmquist index method to conduct the empirical study on the total factor productivity growth of 30 provinces (cities) in China from 2000 to 2009. The results show that technological progress is the main factor to promote the increase of total factor growth rate of tourism in China. Zhang Bairui uses the static local equilibrium research method to calculate that the full employment contribution of tourism in Beijing is 1300; the tourism employment multiplier in Beijing is 2.4, indicating that tourism employment structurein Beijing is relatively balanced, thus verifying the employment multiplier effect of tourism.

Domestic scholars' researches of the tourism industry in ethnic minority areas mainlyfocuson three aspects. First, they investigate and analyze the the status quo of tourism in ethnic areas, the developmenteffectiveness, the problems. Second, they conduct positioning and planning of the tourism industry in the ethnic areas in the macroeconomic policy level. Third, analyze the relations between the tourism industry and economic growth and industrial relations in the ethnic areas. At present, there are few studies on tourism and economic growth in minority areas and the income gap narrowing between urban and rural residents andthe per capita net income increase of farmers. This paper takes data of Bazhou and Jing County as an example to conduct empircal analysis of the influence of the tourism industry in the minority areas on the economic development and per capita net income increase of farmers of Bazhou and Jing County,

\section{Theoretical Evidence for Tourism's Promotion of Economic Growth and Farmers' Income Increase in the Ethnic Areas}

The role of tourism industry on the economic growth of ethnic areas is mainly reflected in the economic effects of tourism, namely, income effect, foreign exchange effect, employment effect and industrial correlation effect. The income effect of tourism reflects the relationship between tourism revenue growth and economic growth. According to the theory of macroeconomics, through the initial distribution and reallocation, the number of the income of tourism used for productive investment and living consumption will be increased with each distribution behavior, and ultimatelyform the tourism multiplier effect, so as to increase the total income of the national economy.

The exchange effect of the tourism industry usually means that the tourism destination countries or regionsdevelop tourism and can directlyobtain a large number of foreign exchange income from the tourism consumption of foreign tourists, including all the tourism expenses that the foreigners in inbound tourism, overseas Chinese, Hong Kong, Macao compatriots in the tourism process in the mainland of China.

The employment effect of the tourism industryrefers to the employment opportunities for the 
local place created by the development of the tourism industry, mainly including direct employment of tourism and indirect employment of tourism. Tourism is a labor-intensive tertiary industry, so the development of tourism can directly or indirectly create a large number of jobs. The World Travel Travel Council (WTTC) estimates tourism multipliers in all regions of the world, with a multiplier of $€ 2.5$ to 3.0, that is, an increase ofeach additional job in the tourism industry leading to three indirectpeople. The industry-related effect of tourism mainly refers to the relationship between the tourism industry and the tertiary industry, that is, whether the three industrial structures in the region are optimizedafter tourism development and the impact of the tourism industry on the primary industry, the secondary industry and the tertiary industry.

At present, the study on the promotion of farmers' income is not common. Therefore, according to the actual factors that affect the increase of farmers' incomes and the actual situation of tourism, this research holds that to reduce the income level of urban and rural residents in tourism places, increase the employment opportunities of farmers in thetourism industry and transfer the rural surplus labor forceto the tourism industryis an important way to promote farmers' income.

According to the theory of development economics, the dual economy is a common phenomenon in developing countries. In China, the dual economic structure of urban and rural separation is more obvious and the restriction on economic development is more prominent. Coordinating the development of urban and rural areas is an important manifestation of implementing the scientific concept of development. Urban and rural plan means to fully exert the support and regurgitationfeeding role of industry to agriculture, the urban radiating and boosting role to rural areas, set up the long-term mechanism of promoting agriculture with industry and boosting village with cities, promote the urban and rural coordinated development and finally realize the development pattern with urban and rural win-win as the purpose. Under the influence of the dual economic structure, the tourism industry can form a balance between urban development and rural development. Tourism development can become an important role in promoting the development of urban and rural integration and become the basic force to promote urban and rural development.

The tourism industry has a significant effect on the transfer of rural surplus labor. First, the tourism industry is a labor-intensive industry, so it can create a large number of employment opportunities. Second, the employment access threshold of tourism is low, providing farmers with employment opportunities. Finally, the tourism employment has strong seasonal features. Usually the tourist peak season is also a slack season of agriculture, which alsoprovides additional employment opportunities for the urban and rural migrant workers with strong mobility.

\section{Empirical Analysis of Tourism Industry's Promoting Farmers' Increase Income}

The total tourism income of Bazhou and Jing County refers to all the monetary income gained through the sale of tourism products. The total tourism income in the statistical yearbook includes the following two: domestic tourism income and tourism foreign exchange income. The domestic tourism income has two indicators: overnight tourism income and one-day touristincome. The total tourism revenue Bazhou and Jing County has been in rapid growth (see Table 1);

Chart 1 Total Tourism Income of Jing County from 2002 to 2014 Unit: 100 million yuan

\begin{tabular}{|l|l|l|l|l|l|l|l|l|l|l|l|l|l|}
\hline $\begin{array}{l}\text { Ye } \\
\text { ar }\end{array}$ & $\begin{array}{l}200 \\
2\end{array}$ & $\begin{array}{l}200 \\
3\end{array}$ & $\begin{array}{l}200 \\
5\end{array}$ & $\begin{array}{l}200 \\
6\end{array}$ & $\begin{array}{l}200 \\
7\end{array}$ & $\begin{array}{l}200 \\
8\end{array}$ & $\begin{array}{l}200 \\
9\end{array}$ & $\begin{array}{l}201 \\
0\end{array}$ & 2011 & $\begin{array}{l}201 \\
2\end{array}$ & $\begin{array}{l}201 \\
3\end{array}$ & $\begin{array}{l}201 \\
4\end{array}$ \\
\hline & 1.72 & 1.62 & 5.31 & 6.8 & 8.3 & 10.0 & 10.5 & 11.5 & 15.2 & $\begin{array}{l}21.5 \\
4\end{array}$ & 30 & 38 & 45.7 \\
\hline
\end{tabular}

Data source: yearbook material arrangement of Bazhou from 2002 to 2015

The total tourism income of Bazhou and Jing County has been in the rapid growth (see Table 2);

Chart 1 Pure Income of Framers and Herdsman in Jing County from 2002 to 2014 Unit: Yuan 


\begin{tabular}{|l|l|l|l|l|l|l|l|l|l|l|l|l|l|}
\hline $\begin{array}{l}\text { Y } \\
\text { ea } \\
\mathrm{r}\end{array}$ & $\begin{array}{l}200 \\
2\end{array}$ & $\begin{array}{l}200 \\
3\end{array}$ & $\begin{array}{l}200 \\
4\end{array}$ & $\begin{array}{l}200 \\
5\end{array}$ & $\begin{array}{l}200 \\
6\end{array}$ & $\begin{array}{l}200 \\
7\end{array}$ & $\begin{array}{l}200 \\
8\end{array}$ & $\begin{array}{l}200 \\
9\end{array}$ & $\begin{array}{l}201 \\
0\end{array}$ & $\begin{array}{l}201 \\
1\end{array}$ & 2012 & 2013 & 2014 \\
\hline $\begin{array}{l}285 \\
1\end{array}$ & $\begin{array}{l}317 \\
9\end{array}$ & $\begin{array}{l}348 \\
1\end{array}$ & $\begin{array}{l}380 \\
8\end{array}$ & $\begin{array}{l}414 \\
3\end{array}$ & $\begin{array}{l}478 \\
3\end{array}$ & $\begin{array}{l}529 \\
4\end{array}$ & $\begin{array}{l}661 \\
6\end{array}$ & $\begin{array}{l}820 \\
1\end{array}$ & $\begin{array}{l}915 \\
4\end{array}$ & $\begin{array}{l}1088 \\
1\end{array}$ & $\begin{array}{l}1248 \\
2\end{array}$ & $\begin{array}{l}1257 \\
0\end{array}$ \\
\hline
\end{tabular}

Data source: yearbook material arrangement of Bazhou from 2002 to 2015

(2) Model design

1. Model: $\mathrm{Y}=\mathrm{ax}+\mathrm{c}$

$\mathrm{a}$ is the undetermined coefficient, and $\mathrm{c}$ is the constant to be determined.

The data in Table 1 and Table 2 are calculated using EVIEWS6 software. The results are shown in Table 3

\section{Chart 3 Model Least Squares Linear Regression Table}

Dependent Variable: Y

Method: Least Squares

Date: 11/27/16 Time: 20:18

Sample (adjusted): 20022013

Included observations: 12 after adjustments

Coefficient Std. Error t-Statistic Prob.

$\begin{array}{lllll}\mathrm{C} & 2329.007 & 233.8254 & 9.960453 & 0.0000 \\ \mathrm{X} & 229.4953 & 10.80863 & 21.23260 & 0.0000\end{array}$

R-squared

$0.978300 \quad$ Mean dependent var

6239.417

Adjusted R-squared

0.976130

S.D. dependent var

3230.208

S.E. of regression

499.0678

Akaike info criterion

15.41437

Sum squared resid

2490687. Schwarz criterion

15.49519

Log likelihood

-90.48624 Hannan-Quinn criter.

15.38445

F-statistic

450.8233

Durbin-Watson stat

0.757391

$\operatorname{Prob}($ F-statistic)

0.000000 
$\operatorname{SE}(233.8254)(10.80863)$

$\mathrm{t}:(9.960453)(21.23260)$

The coefficient of $\mathrm{R}$ is 0.9783 , which indicates that the degree of linear regression is very high. Seen from the regression results, we can see that there are some correlations between the per capita net income of farmers and the total income of tourism in Jing County. When the comprehensive income of tourism increases 10 million yuan, the per capita net income of farmers will increase 229.4953 yuan;

\section{Conclusion and Policy Suggestions}

This paper chooses the total income of tourism and the per capita net income of farmers in 20022004. The study find that: the per-county tourism revenue increases each 100 million yuan, per capita net income of farmers will increase 229.4953 yuan correspondingly. Therefore, the tourism industry in Jingxian County is an indirect effect on the improvement of farmers' net income.

(1) Remain firm that the tourism industry is the economic growth pole of Jing County

From the perspective of economic development, this is also the application of economic growth pole theory in backward and remote Chinese ethnic areas. The successful mode of Jing County can provide a reference for other national autonomous areas to be developed.

(2) Conduct the overall development of urban and rural areas, and strengthen the driving effect of the tourism industry on the suburban economy

Dual economy is an important feature of China's macro economy. In the ethnic areas, the urban and rural separation is also prominent; the dual economy also restricts the economic development of ethnic areas. Study the rural problems and urban issues, use the accumulated funds, technology, management advantages in urban development, activate the advantages of rural resources, develop the rural tourism economy, promote the balanced development of urban and rural areas, which is an important way to achieve the common goal of urban and rural residents of getting rich.

(3) Innovate the tourism development model, and promote the rural tourism development

The development of tourism in ethnic areas is concentrated in the urban areas. Therefore, for rural farmers who have not been transferred to the tourist cities, they have not really enjoyed the benefits of the development of tourism economy, and the development of ethnic and rural tourism is a good complement to the traditional tourism development model. Village economy is one of the important forms of this kind of ethnic rural tourism mode, which can make the local farmers really participate in the tourism industry and make the local farmers' employment channels and income sources show diversified trend.

(4) Strengthen the farmers' tourism vocational skills training, improve the quality of tourism practitioners

Despite the low barriers to employment in the tourism industry, it is still necessary to carry out tourism vocational training for tourism practitioners. Tourism is a typical service industry; the quality of its practitioners will significantly affect the tourists' feelings on the tourist places, and thus affect the image of tourism city. Especially in the tourist cities in the ethnic areas that foreign tourists favor, if the practitioners cannot be improved in the cultural differences, language barriers, communication skills, it will greatly affect the income of practitioners.

\section{Acknowledgment}

National cultural science and technology support project: comprehensive service system and application project of Tarim cultural tourism (2013BAH27F04)

\section{References}

[1] Wang Yan, Yan Shun, Zhao Cailong Types, Grades and Spatial Distribution Characteristics of Tourism Resources in Xinjiang[J]. Arid Geography, 2009, 32 (5): 783 - 790.

[2] Wang Yan, Wang Zhe, Dong Liangquan. Analysis on the Comprehensive Impact of Economic 
Contribution of Tourism Industry in Xinjiang [J]. Resources and Environment of Arid Land. (04): $167-171$.

[3] Liu Changsheng, Jian Yufeng. Study on the Policy Path and Economic Impact of China's Tourism Development - Panel Data Analysis Based on Different Provinces [J]. Business Economy and Management. 2009 (06): 59 - 65.

[4] Xu Likai, Zhang Chun. An Empirical Analysis on the Development of the Tertiary Industry to Improve the Farmers' Income [J]. Anhui Agricultural Sciences, 2006, 34 (21): 5725 - 5727.

[5] He Manxi. Study on the Relationship between Tourism Economy and GDP [J]. Ecological Economy. 2010 (08): 32 - 34.

[6] Chen Ning. Liaoning Province Tourism Economic Effect Analysis and Countermeasures [D]. Liaoning: Northeast University of Finance and Economics, 2007.

[7] Luo Mingyi. Tourism Economy Analysis-Theory, Method, Case [M]. Yunnan: Yunnan University Press, 2001.36.

[8] Lin Nanzhi, Tao Hanjun. Tourism Economics [M]. Tianjin: Nankai University Press, 2001.1112.

[9] Tian Li. Tourism Economics [M]: Beijing: Higher Education Press, 2003.

[10] Chu Yifang. Travel Space Economic Analysis [M]. Tianjin: Nankai University Press, 2001. 